\title{
Pengembangan Kemandirian Kelompok Difabel Melalui Pemanfaatan Pemasaran Digital di Kota Magelang
}

\author{
Lintang Citra Christiani*1, Prinisia Nurul Ikasari², Fitria Khairum Nisa ${ }^{3}$ \\ 1,2,3 Program Studi Ilmu Komunikasi, Fakultas Ilmu Sosial dan Ilmu Politik, Universitas Tidar \\ *e-mail: lintang.citra@untidar.ac.id ${ }^{1}$, prinisia.nurul@untidar.ac.id ${ }_{2}{ }_{2}$ fitriaknisa@untidar.ac.id ${ }^{3}$
}

\begin{abstract}
Different physical or nonphysical conditions bring the disabled group into the depletion chain, both socially, politically, and economically. It started from the low access to education to low uptake in the industrial world. The effort to break the depletion chain is to develop the self-sufficiency of children with disabilities and independence from the Gerakan untuk Kesejahteraan Tunarungu Indonesia (Gerkatin) through the guidance of digital marketing utilization. The empowerment approach is used in this activity from the start of planning activities, implementation, to evaluation through participatory methods and learning by doing. From the results of community devotion activities, the target group becomes more economically independent with digital marketing skills and shifting the gadget addiction to more rewarding online activities. The formation of Magelang Disabled Digital Interprenenur Community is an effort to ensure the continuity of the program
\end{abstract}

Keywords: difabel, empowerment, digital marketing, magelang

\begin{abstract}
Abstrak
Kondisi fisik atau nonfisik yang berbeda membawa kelompok difabel masuk ke dalam rantai pemiskinan, baik secara sosial, politik, maupun ekonomi. Dimulai dari rendahnya akses pendidikan hingga rendahnya serapan di dunia industri. Upaya untuk memutus rantai pemiskinan tersebut adalah mengembangkan kemandirian kelompok anak difabel dan kemandirian dari kelompok Gerakan untuk Kesejahteraan Tunarungu Indonesia (Gerkatin) melalui pendampingan pemanfaatan pemasaran digital. Kelompok sasaran dibatasai pada kelompok anak difabel kategori B (tunarungu) dengan rentang usia 15-18 tahun yang akan segera lulus sekolah dan kelompok Gerkatin di Kota Magelang kategori B dengan usia maksimal 25 tahun. Pendekatan pemberdayaan digunakan dalam kegiatan ini dari mulai perencanaan kegiatan, implementasi, hingga evaluasi melalui metode partisipatif dan learning by doing. Dari hasil pengabdian, kelompok sasaran menjadi lebih mandiri secara ekonomi dengan pemahaman dan keterampilan pemasaran digital serta mengalihkan kecanduan gawai kepada aktivitas online yang lebih bermanfaat. Terbentuknya komunitas Digital Interprenenur Difabel Magelang menjadi upaya menjamin keberlangsungan program pengabdian.
\end{abstract}

Kata Kunci: difabel, pemberdayaan, pemasaran digital, magelang

\section{PENDAHULUAN}

Menurut Pasal 1 UU No.4 Tahun 1997 Tentang Penyandang Cacat, pengertian penyandang cacat atau disabilitas adalah 'setiap orang yang mempunyai kelainan fisik atau mental yang dapat menghambat baginya untuk melakukan sesuatu secara selayaknya'. Ketidaksempurnaan fisik maupun nonfisik sering dianggap sebagai kekurangan, ketidaksempurnaan, tidak normal atau cacat. Pandangan inilah yang kemudian membatasi ruang gerak kelompok berkebutuhan khusus dalam masyarakat, baik secara sosial, ekonomi, maupun politik. Istilah difabel kemudian menjadi istilah yang lebih sering digunakan untuk mewakili penyandang disabilitas karena menunjukkan bahwa cacat bukan merupakan suatu kekurangan, tetapi sebuah kemampuan yang berbeda dalam melakukan sesuatu (differently able).

Badan Pusat Statistik mencatat, jumlah Anak Berkebutuhan Khusus (ABK) dalam kategori penyandang disabilitas adalah 9,9 juta pada 2013. Data dari Kementaerian Pendidikan dan Kebudayaan menyebutkan, ada sejumlah 1,6 juta anak berkebutuhan khusus di Indonesia. Dinas Sosial Provinsi Jawa Tengah mempublikasikan bahwa jumlah anak dengan disabilitas 47.582 dan secara khusus Kota Magelang mencatat dalam RPJMD Kota Magelang tahun 2016 (Pemkot Magelang, 2016: 100), pada tahun 2015 jumlah Anak dengan Kedisabilitasan (ADK) adalah 324 yang terdiri dari tuna daksa, tuna netra, bisu tuli, tuna grahita, tuna laras, serta disabilitas ganda 
(fisik dan mental). Melihat data tersebut, keberadaan kelompok ini seharusnya menjadi perhatian dari berbagai pihak untuk mendapatkan jaminan sosial dan perlindungan.

Dinas Sosial Provinsi Jawa Tengah menyatakan, secara garis besar, sikap dan pandangan masyarakat terhadap anak difabel adalah lemah serta tidak berguna. Bahkan sebagian masih menganggap keberadaan anak-anak difabel sebagai sebuah aib. Stigma "keterbelakangan", "lemah", "rendah" yang melekat pada kelompok ini membuat mereka tereksklusi dari lingkungan masyarakat dan menjadi miskin secara sosial.

Rantai pemiskinan dan peminggiran ini bemula dari banyaknya orang tua yang tidak menyekolahkan anak difabel karena malu dengan kondisi anaknya atau anggapan bahwa anak tersebut tidak akan bisa mengikuti proses belajar di sekolah. Kalau pun mereka bersekolah dan diajarkan berbagai keterampilan, ketika lulus mereka sulit mencari pekerjaan karena sangat sedikit industri yang menerima tenaga difabel. Akhirnya banyak pula yang kemudian menganggur dan hidup di bawah garis kemiskinan. Kondisi inilah yang terjadi pada kelompok difabel di Kota Magelang sehingga diperlukan upaya untuk memotong rantai pemiskinan ini melalui pengembangan kemandirian kelompok adifabel.

Jika melihat dari sisi potensi, kelompok difabel di Kota Magelang, terutama yang sudah dapat mengakses pendidikan di sekolah, sangat berbakat dalam berbagai bidang. Berdasarkan data dari koordinator Forum Anak Difabel, anak-anak difabel yang bersekolah banyak yang menjuarai berbagai lomba, diantaranya lukis, merias wajah (make-up), menjahit, membuat batik, kerajinan dari olahan limbah serta barang bekas, dan sebagainya. Produk yang dihasilkan pun pernah dipamerkan di tingkat nasional. Namun demikian pameran tersebut hanya berlangsung sesaat dengan sosialisasi yang masih terbatas. Karena hasil karyanya yang unik dan berkualitas, tidak jarang produk dari kelompok anak difabel ini juga dibeli oleh para pejabat daerah maupun pusat, tetapi hanya berhenti sampai di situ karena hambatan-hambatan dalam berkomunikasi dengan masyarakat.

Pengguna lulusan SLB, terutama pengguna lulusan SLB-B (untuk bagian tunarungu) menceritakan bahwa kelompok difabel memiliki ketekunan dan ketelitian yang tinggi. Karena keterbatasan yang dimiliki, mereka tidak bisa banyak menghabiskan waktunya untuk berbincang dengan rekan sekerjanya sehingga pekerjaan cepat sekali diselesaikan. Hal ini yang tidak banyak diketahui oleh masyarakat.

Selain itu, kelompok difabel juga sudah aware dengan penggunaan perangkat gawai dan aktivitas online. Mereka cukup terampil menggunakannya untuk aktivitas berkomunikasi seharihari bahkan banyak yang ketergantungan dengan gadget-nya. Mereka tidak bisa lepas dari perangkat tersebut hingga seringkali mengabaikan kegiatan-kegiatan yang penting, salah satunya belajar.

Perkembangan teknologi dapat membawa dampak negatif, tetapi juga dapat memberikan manfaat yang besar, tergantung dari bagaimana manusia meresponnya. Perangkat gawai dan perkembangan teknologi termasuk salah satu faktor yang dapat memutus rantai pemiskinan kelompok difabel terhadap akses informasi dan komunikasi serta dapat membuka ruang bagi pemberdayaan kelompoknya untuk mandiri dalam penghidupan (Sucahyo, 2019). Digital marketing relevan untuk menjadi basis kemandirian ekonomi masyarakat. Pelatihan pemasaran digital dalam kegiatan pengabdian bagi UMKM menghasilkan peningkatan penjualan produk, peningkatan jumlah konsumen, meluasnya jaringan promosi, dan meminimalkan dana pemasaran dengan brosur (Novita dalam Azizah dkk, 2019: 134). Digital marketing memungkinkan produsen dan penjual memperoleh seluruh informasi mengenai produk dengan murah dan mudah dan pada saat yang sama penjual dapat memantau dan menyediakan kebutuhan konsumen tanpa batasan waktu dan wilayah (Hadi dan Khairi, 2020: 131). Namun demikian, belum banyak upaya untuk memanfaatkan perkembangan teknologi tersebut bagi pengembangan kemandirian kelompok difabel dalam bidang sosial dan ekonomi secara berkelanjutan. 


\section{METODE}

Kelompok sasaran kegiatan pengabdian masyarakat ini adalah kelompok anak difabel kota Magelang kategori B (tunarungu) dengan rentang usia 15-18 tahun yang akan segera lulus sekolah dan kelompok Gerkatin (lulusan SLB) Magelang kategori B dengan maskimal usia 25 tahun. Pemilihan target ini ditentukan berdasarkan hasil analisis situasi dan kekhususan keahlian dari tim pengabdian. Selanjutnya, kegiatan pengabdian ini menerapkan pendekatan pemberdayaan, yaitu dengan mengikutsertakan kelompok sasaran dari proses perencanaan, pelaksanaan kegiatan, hingga evaluasi. Pendektaan pratisipatif dalam pemberdayaan masyarakat, tidak hanya memberikan ruang untuk bersuara bagi mitra pengabdian, tetapi juga power dalam pengambilan keputusan (Rahman, 2016: 11-12). Oleh karena itu dalam kegiatan ini, dari sejak perencanaan mitra diajak bernegosiasi dengan tim pengabdian.

Kelompok sasaran secara partisipatif turut mengidentifikasi masalah melalui pengalamannya sehingga kegiatan pengabdian betul-betul menjawab kebutuhan yang menjadi prioritas (problem solving) bagi mereka sendiri. Langkah ini masuk pada tahap perencanaan program kemitraan masyarakat. Dengan metode partisipatif ini diharapkan solusi dapat diterapkan dengan cara yang tepat dan berkelanjutan.

Berdasarkan tujuan dari program pengabdian, pelaksanaan kegiatan dilakukan melalui 2 tahap. Tahap pertama adalah tahap penyampaian materi, praktik, dan pendampingan pemasaran digital. Kegiatan ini dilakukan dalam bentuk ceramah, diskusi, tanya jawab dan simulasi, praktik langsung, sehingga kegiatan dapat berjalan dua arah tanpa ada batasan antara tim pengabdian dan peserta pengabdian. Diharapkan selama proses berlangsung dapat tercipta suasana yang aktif dan interaktif. Dengan demikian jika terdapat materi yang disampaikan oleh tim pengabdian belum begitu dipahami oleh peserta dapat didiskusikan dengan lebih maksimal. Strategi yang dilaksanakan adalah learning by doing dengan pemahaman bahwa pemberdayaan ialah proses belajar sekaligus dengan praktik.

Tahap kedua, pelaksanaan program berupa manajemen promosi secara berkelanjutan melalui pembentukan Komunitas Difabel Penggiat Pemasaran Digital. Kegiatan ini mendorong kemandirian kelompok sasaran sehingga pada akhirnya mampu mengorganisir diri dan komunitasnya bahkan dapat menularkan ilmu dan keterampilannya pada anggota kelompok difabel lain yang belum mengikuti program ini. Dalam pemberdayaan komunitas marginal melalui metode partisipatif, Arnstein menyampaikan mengenai pendekatan partisipatif yang memiliki klaim-klaim untuk mengukur prosesnya berjalan dengan benar, salah satunya adalah redistribusi power (Rahman, 2016: 12-13). Pembentukan komunitas ini diharapkan menjadi bentuk dari pelimpahan kekuasaan sehingga mitra yang sebelumnya terpinggirkan memiliki ruang untuk bersuara bahkan menjadi subyek-subyek yang menentukan perkembangan komunitasnya.

Setelah dua pertemuan tersebut dilaksanakan selanjutnya akan diadakan evaluasi kegiatan baik dalam hal penyampaian materi, seberapa terserap materi yang diterima peserta, ada dan tidaknya kendala selama kegiatan berlangsung, serta bagaimana target capaian yang ada. Evaluasi dilakukan melalui angket yang berisi pencapaian sasaran program yang akan diisi oleh kelompok sasaran. Evaluasi yang dilakukan nantinya dapat dijadikan acuan untuk melakukan kegiatan lainnya yang sejenis atau sebagai bahan pelaporan atas seluruh rangkaian kegiatan yang telah berlangsung.

\section{HASIL DAN PEMBAHASAN}

Berdasarkan data analisis situasi terdapat beberapa permasalahan pokok yang dihadapi oleh kelompok anak difabel. Solusi yang ditawarkan pada intinya adalah pemutusan rantai pemiskinan kelompok sasaran dengan mengembangkan kemandirian di bidang ekonomi dan sosial melalui pemanfaatan perkembangan teknologi. Pemasaran digital dipilih sebagai peluang yang dapat dikembangkan oleh mitra. Digital marketing merupakan strategi-strategi yang direncanakan secara terintegrasi menggunakan media sosial, mesin pencarian, email, dan 
berbagai konten promosi. Internet memberikan ruang bagi prkatik pemasaran dan kontenkontennya dapat berupa teks, audio, visual, maupun audio-visual (Kusuma dan Sugadi, 2018: 20).

Pertama, kelompok anak difabel akan diajak untuk mengenal fitur-fitur aplikasi di media sosial yang dapat dimanfaatkan untuk pengembangan pemasaran secara online. Kelompok sasaran diberikan sosialisasi mengenai manfaat gawai dan media sosial, selain untuk komunikasi sehari-hari dan mengekspresikan diri. Kedua, kelompok sasaran diajarkan, diajak praktik, dan didampingi dalam menggunakan aplikasi di media sosial untuk memperkenalkan produk atau hasil karya ciptanya dengan menggunakan fitur-fitur di aplikasi media sosial, salah satunya melalui pembuatan akun Instagram for Business. Ketiga, kelompok sasaran diajarkan strategi foto produk (product photography) sederhana dengan memanfaatkan perangkat gawai, penulisan caption yang menarik, menggunakan aplikasi product design hingga pendampingan dalam praktik pemasaran digital. Keempat, kelompok sasaran didampingi untuk mencoba mempraktikkan social media marketing untuk memasarkan produk secara online dengan membuat akun pengrajin difabel. Selanjutnya mencoba untuk mengunggah foto produk yang telah didesain dengan menarik hingga pembuatan caption seperti yang telah diajarkan sebelumnya. Adapun materi yang akan diberikan antara lain:

- Praktik pelatihan pengambilan foto produk yang baik

- Praktik pelatihan desain gambar menggunakan aplikasi sederhana

- Pendampingan pembuatan akun media sosial untuk pemasaran digital

- Praktik pelatihan pembuatan caption (keterangan gambar) untuk promosi di media social

- Pelatihan strategi pemasaran menggunakan media sosial

- Pendampingan pembuatan akun media sosial untuk pemasaran digital

Berdasarkan rangkaian kegiatan dan pertemuan tersebut maka luaran yang diharapkakan dari pelaksanaan program pengabdian pada masyarakat ini adalah sebagai berikut:

1. Kelompok sasaran memiliki akun media sosial untuk mempromosikan segala bentuk karya (barang dan jasa) yang dibuat oleh perajin difabel. Diantaranya akun Facebook dan Instagram for business.

2. Kelompok sasaran mampu mengambil foto produk dengan kualitas yang baik untuk kemudian menjadi materi promosi di media sosial yang telah dibuat.

3. Kelompok sasaran tidak hanya dapat mengambil foto, tetapi juga mampu membuat desain tampilan produk agar lebih menarik di media sosial.

4. Dibentuknya Komunitas Difabel Penggiat Pemasaran Digital (Digipreneur) untuk kemudian dapat terus melanjutkan pelatihan pemasaran digital untuk generasi selanjutnya.

Dalam upaya mencapai tujuan dan target yang telah ditetapkan, tim pengabdian menentukan jenis kepakaran yang diperlukan dalam menyelesaikan persoalan mitra tersebut, yaitu kepakaran dalam pemasaran digital, foto produk, desain produk, serta keahlian khusus pengisyarat bagi difabel. Pemateri pertama memiliki kepakaran di bidang desain komunikasi visual dan fotografi akan memberikan bekal kepada peserta mengenai foto produk. Pemateri kedua merupakan social media specialist sekaligus pengisyarat tunarungu yang akan mengajak diskusi mengenai editing dan desain foto sehingga menjadi menarik di media sosial. Selanjutnya, pemateri ketiga memiliki kepakaran di bidang strategi branding dan literasi media yang akan banyak memberikan materi mengenai pemanfaatan sosial media untuk pemasaran digital. Kelayakan dari pemateri sangat menentukan ketercapaian dari setiap kegiatan yang dilakukan.

Sesuai dengan metode pengabdian dan rancangan yang telah dibuat, pengabdian dilakukan dalam dua tahapan. Tahapan pertama, kegiatan pengabdian kepada masyarakat dilaksanakan pada 13-14 Februari 2020 ini diikuti oleh 30 peserta dari Forum Anak Difabel Kota Magelang dan komunitas Gerkatin Magelang. Bertempat di SLB-B YPPALB Kota Magelang, para peserta mengikuti pelatihan dengan antusias. Tahapan pertama ini membangun basis strategi pemasaran digital, khususnya kemampuan menyajikan konten (content strategy). Dalam 
pemasaran digital, konten yang akan dimasukkan ke dalam berbagai platform media digital dan dikonsumsi oleh khalayak. Konten yang dimaksud tidak hanya konten yang berfungsi sebagai media promosi melainkan juga konten yang bagus dan menarik secara visual (Alagöz dan Ekici, 2016: 641). Selain penyajian konten, tahapan pertama dalam pengabdian juga mengarah pada pemanfaatan media sosial bagi pengembangan produk. Seperti kita ketahui, media sosial sangat populer untuk meningkatkan awareness terhadap produk. Fitur-fitur di dalam media sosial membantu dalam membuat dan menyajikan informasi, ide, gambar atau foto, dan video. Media sosil dipilih sebagai platform utama yang dipelajari karena sangat interaktif dengan keuntungan lain yaitu meraih jangkauan konsumen yang luas. Strategi sosial media juga merupakan model binis yang dapat diterapkan dalam promosi berbagai jenis produk (Kingsnorth, 2016: 32).

Sebelum kegiatan ini dilakukan, ada riset terlebih dahulu mengenai kondisi anak difabel dan kelompok difabel secara umum serta perkenalan sehingga materi-materi dapat diterima dengan baik. Dalam pelaksanaan, tim pengabdian menerapkan metode partisipatif dengan proses menggali sumber daya dari komunitas atau kelompok sasaran (discovery), menggali harapan dan impian komunitas (dream), serta memetakan potensi kelompok sasaran (design). Langkahlangkah ini merujuk pada langkah-langkah pemberdayaan berbasis asset (Sholehah, 2017: 164165). Pola pikir yang dibangun dalam pemberdayaan ini bukan berdasar pada belas kasihan melainkan pada upaya pemenuhan hak dan peningkatan power dalam bentuk penguatan skill.

Hari pertama terdiri dari dua sesi, yaitu sesi foto produk dan desain foto produk. Peserta diajarkan mengenai dasar-dasar foto produk untuk pemasaran digital. Sesi pertama ini dimulai dengan penyampaian mengenai bagaimana konsumen mengambil keputusan membeli dari melihat foto-foto katalog produk. Sebuah penelitian menuliskan hasil bahwa elemen-elemen dalam foto produk secara visual mengandung informasi yang berguna mengenai penggunaan produk, konteks produk, dan akan dapat menarik perhatian serta persepsi konsumen (Hoai Do, 2018: 44-46). Foto produk merupakan bagian dari advertising yang mana kunci keberhasilannya terletak pada angle dan juga konsep. Pemateri menjelaskan bahwa ada beberapa langkah dalam foto produk, yaitu menyiapkan background foto, pemilihan model dan penggunaan produk dalam foto, pencahayaan, dan angle foto. Materi yang diterapkan sesuai dengan lahkah-langkah dalam produksi foto yang menekankan pada pemahaman mengenai pencahayaan, background, komposisi foto dan bagaimana foto menyampaikan cerita (Kretova dalam Purwanto dan Veranita, 2018: 208).

Karena peserta pelatihan adalah difabel kategori B (tunarungu), maka penyampaian materi banyak menyertakan gambar-gambar dan contoh-contoh penerapannya (visual), bukan saja tulisan dan teori. Kemudian pemateri juga benyak menggunakan komunikasi nonverbal dalam menjelaskan konsep dan teknik. Agar pesan tersampaikan dengan baik, peserta pelatihan dibagi dalam kelompok-kelompok kecil berisi 4-5 orang, yang mana setiap kelompok akan didampingi oleh fasilitator maupun guru SLB. Fasilitator di sini terdiri dari pengisyarat maupun alumni dari SLB.

Sebelum kegiatan berlangsung, peserta diminta untuk membawa gawai sebagai prangkat yang akan dimanfaatkan dalam kegiatan pelatihan sekaligus juga membawa produk-produk yang telah dihasilkan. Setelah materi sesi pertama mengenai foto produk disampaikan, peserta langsung praktik di luar ruangan menggunakan perangkat handphone tersebut. Praktik ini bertujuan memberikan pengalaman secara langsung mengenai foto produk, baik kesenangan maupun kesulitan yang dihadapi dalam proses foto.

Proses praktik ini juga tetap didampingi oleh fasilitator di setiap kelompok. Dalam kegiatan praktik tersebut, kreativitas peserta terasah dibuktikan dengan hasil foto produk yang baik. Peserta bisa menerapkan teori seperti menentukan konsep foto, mempersiapkan background hingga mengatur pencahayaan dalam foto. Foto-foto yang dihasilkan kemudian dikumpulkan untuk ditayangkan dan direview oleh pemateri sehingga peserta mendapat apresiasi dan juga sekaligus masukan ketika masih ada yang perlu diperbaiki dalam hal konsep maupun teknik foto. 


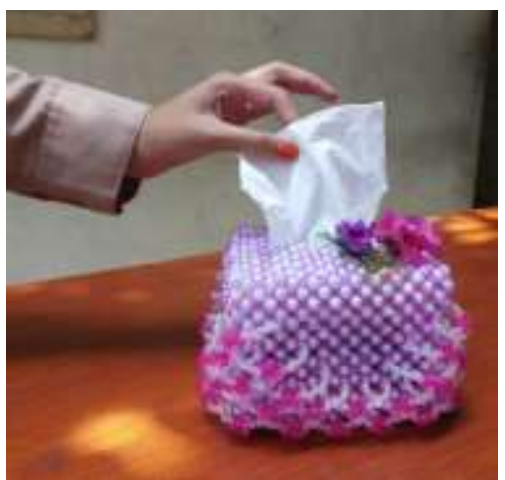

(a)

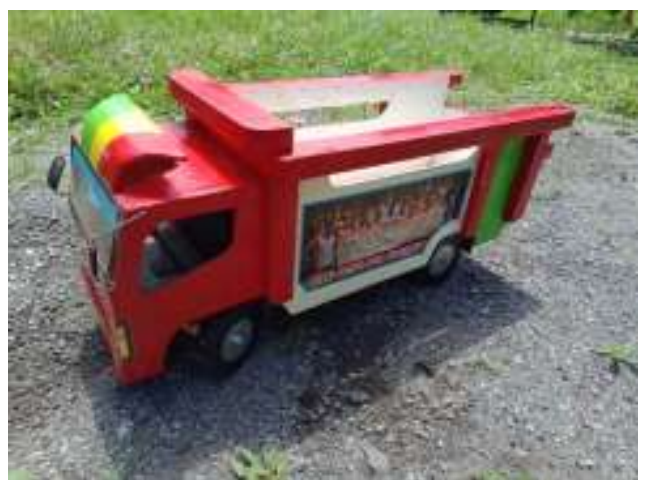

(b)

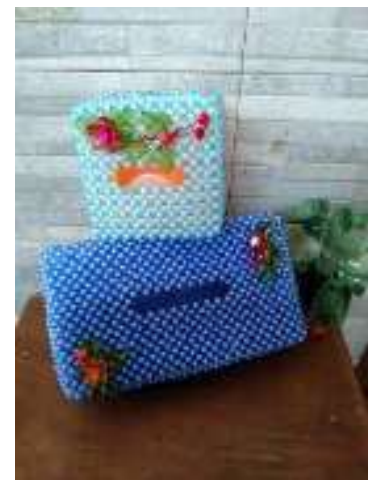

(c)

Gambar 1. Beberapa foto produk peserta $(a, b, c)$

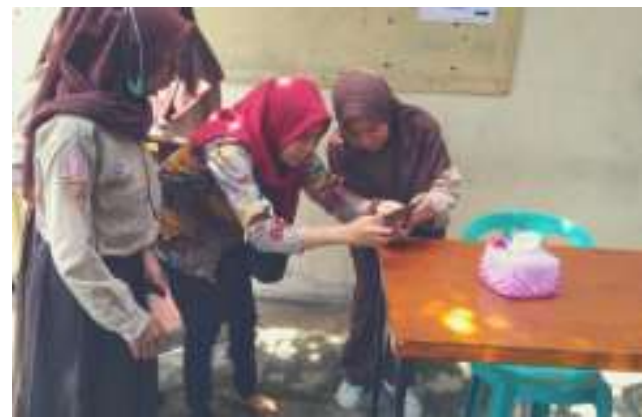

(d)

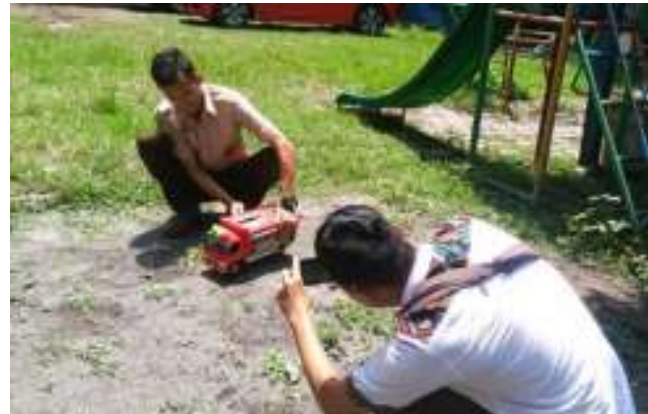

(e)

Gambar 2. Peserta pada waktu praktik foto produk $(\mathrm{d}, \mathrm{f})$

Setelah peserta mampu menghasilkan foto produk yang baik, peserta dibekali dengan cara desain foto pada sesi kedua. Peserta diajak untuk melihat perbedaan dari foto dan foto setelah diedit dan didesain menjadi lebih menarik. Sesi kedua ini bertujuan meningkatkan pemahaman bahwa promosi produk penting dalam pemasaran dan keterampilan membuat media promosi perlu dimiliki. Selain menghasilkan foto produk yang menarik, peserta juga diajarkan untuk membuat brosur promosi produk. Upaya untuk membuat sesi ini menjadi mudah adalah dengan pengenalan aplikasi untuk mengedit foto dan membuat berbagai media promosi, salah satunya canva.

Pada sesi kedua ini lebih banyak diisi dengan praktik editing foto dengan menggunakan aplikasi yang bisa didapatkan secara gratis melalui playstore. Editing foto pada kegiatan ini lebih merujuk kepada desain materi promosi produk menggunakan foto yang diambil. Sebuah penelitian desain menyebutkan bahwa, seiring perkembangan jaman, desain visual yang pada awalnya merupakan alat komunikasi, saat ini sudah digunakan sebagai media promosi (Dewojati, 2009:175-182). Sehingga pada sesi ini peserta diajarkan bagaimana untuk mengolah foto yang sudah diambil menjadi sebuah desain komunikasi visual untuk mempromosikan produk yang para peserta tawarkan agar dapat menarik perhatian calon pembeli. Setelah proses editing dan desain selesai diprkatikkan, peserta mengirimkan hasilnya kepada pemateri untuk kembali direview. Proses review ini juga disertai dengan diskusi dengan peserta. Dalam diskusi, fasilitor dan guru SLB sangat berperan membantu supaya pesan dari peserta dapat tersampaikan dengan baik kepada pemateri, demikian juga sebaliknya.

Sesi ketiga dilanjutkan pada hari berikutnya yang akan membahas mengenai pemanfaatan media sosial bagi pemasaran digital. Peserta diperkenalkan mengenai beberapa aplikasi yang dapat digunakan sebagai media untuk memasarkan produknya, salah satu yang dapat digunakan adalah Instagram for business, melihat sebagian besar peserta sudah memiliki akun Instagram. Instagram adalah media sosial yang telah membantu berbagai perusahaan dalam meningkatkan awareness masyarakat terhadap brand dan membangun basis konsumen yang loyal pada 
produknya (Vinaika dan Manik, 2017: 13-14). Selain itu, Instagram mengombinasikan berbagai strategi seperti seni dalam foto, cerita (storytelling), pengembangan konten, serta menghubungkan konten dengan konsumen. Terlebih lagi, berdasarkan beberapa penelitian dikatakan bahwa iklan dalam media sosial Instagram dianggap efektif karena biaya yang efisien dan jangkauan yang luas (Oktaviani dan Rustansi, 2018:1-20 dan Puspitarini dan Nuraeni, 2019:71-80). Dengan demikian diharapkan Intagram tidak hanya menjadi media untuk para peserta bersosialisasi, tetapi juga bisa dimanfaatkan menjadi media berpromosi.

Peserta diberikan wawasan mengenai fitur-fitur yang ada pada aplikasi tersebut beserta kelebihannya untuk pemasaran digital jika dibandingkan dengan Instagram akun personal yang telah dimiliki. Kemudian kegiatan dilanjutkan dengan praktik langsung pembuatan akun Instagram for business. Sebagian peserta hanya tinggal mengubah akun personal menjadi akun bisnis dan mencoba menggunakan berbagai fitur yang ada di dalamnya. Penyampaian materi dilakukan dengan memberikan tutorial langkah-langkah penggunaan media sosial melalui gambar-gambar. Peserta diminta untuk praktik upload foto-foto produk yang telah didesain sendiri pada akun tersebut.

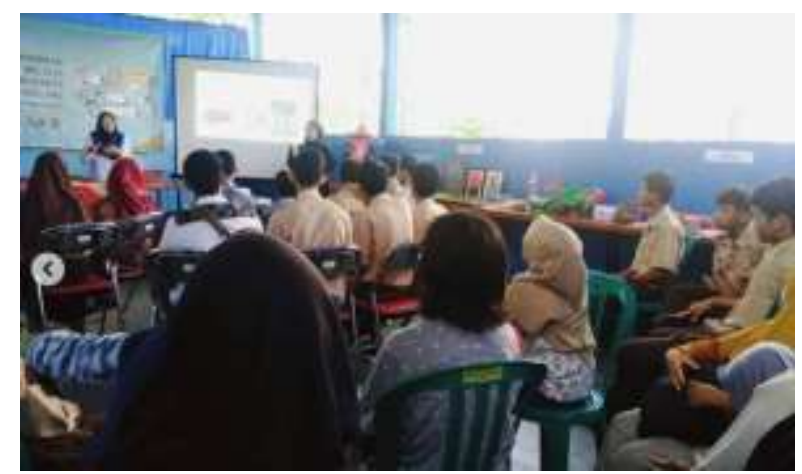

(f)

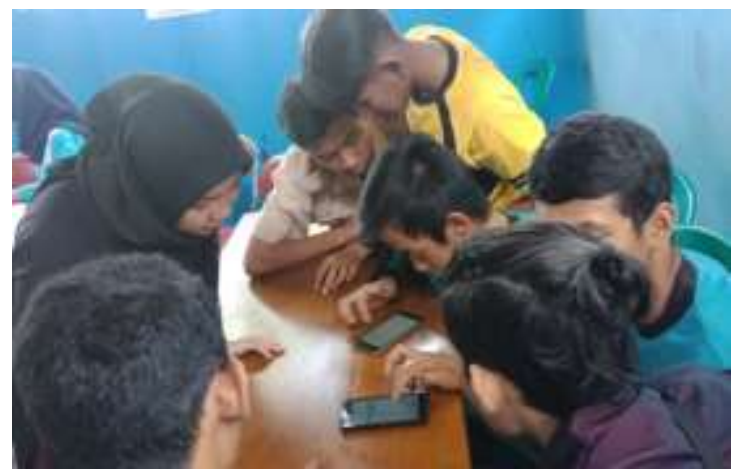

(g)

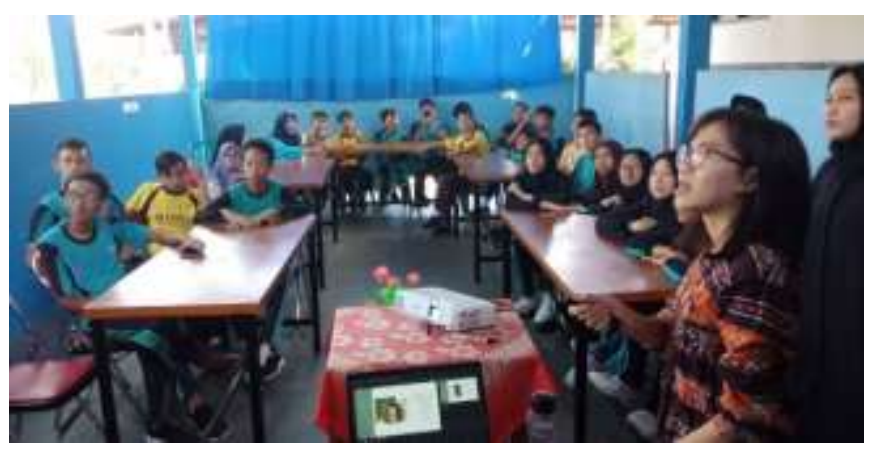

(h)

Gambar 3. Penyampaian materi dan praktik digital marketing.

Sesi pertama (a), Sesi kedua (g), Sesi ketiga (h)

Materi sesi ketiga dilengkapi dengan materi sesi keempat mengenai penyusunan caption yang menarik di media sosial. Peserta yang adalah difabel kategori B ini tentu memiliki keterbatasan dalam komunikasi verbal, termasuk dalam penyampaian gagasan melalui tulisan. Oleh karena itu penyusunan caption di media sosial menjadi target tersendiri yang dapat meningkatkan keterampilan tersebut. Terkhusus dalam pemasaran digital, peserta diajak untuk memahami bagaimana penyusunan caption yang disesuaikan dengan produk, calon pembeli, penggunaan hashtag (\#) dan emoji yang dapat menarik perhatian calon pembeli hingga memanfatkan fitur Instagram Measurement and Analytics.

Hashtag merupakan metode untuk mengelompokkan postingan dalam kategori tertentu, sesuai dengan nama produk, jenis produk, atau slogan dari produk. Selain itu, dalam berbagai penerapan, hashtag dimanfaatkan untuk medukung kampanye dan event yang mungkin sedang 
dilakukan (Scisson, Vo, Sim, 2014: 33-36). Kemudian fitur analisa Instagram dapat digunakan untuk melihta dan mempromisikan positingan atau foto dengan performa terbaik. Dengan fitur ini kita dapat memantau perkembangan jangkauan dan informasi mengenai siapa khalayak yang mengakses dengan keterangan demografis seperti jenis kelamin, kota pengakses, sampai pada waktu akses. Penggunaan hashtag dan fitur analisa Instagram, sama halnya dengan sesi-sesi sebelumnya, materi banyak disampaikan melalui contoh-contoh yang menarik secara visual.

Kedua, pengabdian tahap kedua mengenai manajemen promosi melalui pembentukan komunitas. Jika pada tahapan yang pertama banyak diisi dengan penyampaian materi, diskusi, dan praktik, tahapan kedua ini berisi diskusi mengenai pembentukan komunitas difabel penggiat pemasaran digital untuk menjamin keberlangsungan manajemen promosi produk dan keberlangsungan dalam pemberdayaan kelompok difabel menjadi mandiri dengan berwirausaha. Digital Enterpreneur (Digipreneur) Difabel Magelang disepakati sebagai nama komunitas sekaligus menjadi nama akun di media sosial yang akan terus dikembangkan menjadi wadah promosi produk sekaligus wadah komunikasi bagi komunitas serta masyarakat secara umum.

Komunitas yang kemudian aktif berjalan dengan menggunakan media sosial sebagai sarana komunikasinya dapat memengaruhi khalayak dalam awareness terkait produk-produk yang dihasilkan difabel. Sebuah penelitian mengenai akun media sosial @temandisabilitas_Id, menyampaikan bahwa akun Instagram tersebut dapat meningkatkan pengetahuan followers mengenai difabel (Ramdan, Rismawan, Wiharnis, dan Safitri, 2019: 112-113). Demikian pula harapan dari pembentukan komunitas dan pembuatan akun media sosial.

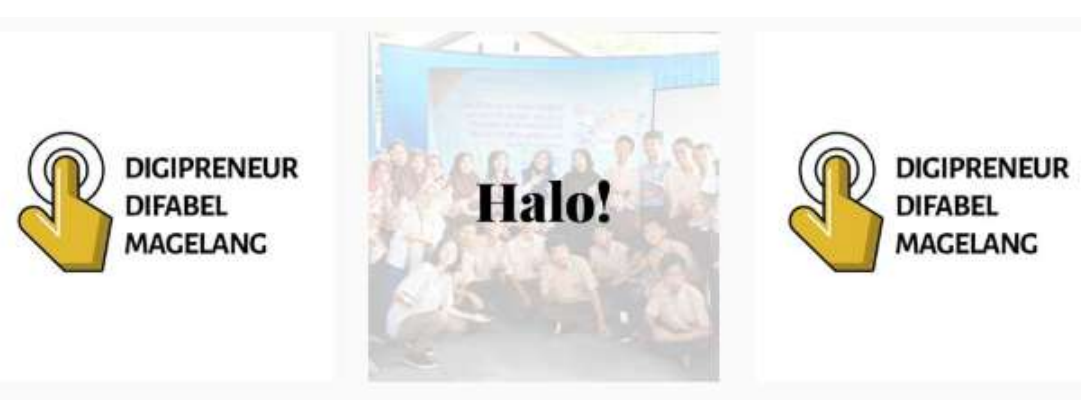

Gambar 4. Media Sosial Instagram dari Komunitas Digipreneur (@digipreneur.difabelmgl)

Kontribusi mendasar dari kegiatan pengabdian ini ialah memberikan bekal pengetahuan dan keterampilan pemasaran digital, mulai dari pengenalan aplikasi media sosial untuk bisnis, foto produk, desain produk, hingga strategi promosi atas produk dan jasa yang dihasilkan oleh kelompok sasaran. Selain itu, program ini juga mendorong kemandirian dari kelompok sasaran untuk berwirausaha dan tidak hanya mengandalkan pihak industri untuk penghidupan. Berkaitan dengan hal tersebut, luaran dari kegiatan ini sebagai berikut:

Tabel 1. Luaran Kegiatan

\begin{tabular}{|c|c|}
\hline Jenis Luaran & Indikator Pencapaian \\
\hline $\begin{array}{l}\text { Peningkatan } \\
\text { pemahaman dan } \\
\text { keterampilan } \\
\text { masyarakat }\end{array}$ & $\begin{array}{l}\text { - Kelompok sasaran memiliki akun } \\
\text { media sosial untuk } \\
\text { mempromosikan segala bentuk } \\
\text { karya (barang dan jasa) yang } \\
\text { dibuat oleh perajin difabel } \\
\text { - Kelompok sasaran mampu } \\
\text { mengambil foto produk dengan }\end{array}$ \\
\hline
\end{tabular}




\begin{tabular}{ll}
\hline & $\begin{array}{l}\text { kualitas yang baik serta membuat } \\
\text { desain produk yang menarik }\end{array}$ \\
& $\begin{array}{l}\text { Terbentuknya Komunitas Difabel } \\
\text { Penggiat Pemasaran Digital untuk } \\
\text { menjamin keberlangsungan } \\
\text { manajemen promosi produk }\end{array}$ \\
& Terpublikasinya artikel pengabdian i \\
$\begin{array}{l}\text { Publikasi pada } \\
\text { media masa } \\
\text { cetak/elektronik) }\end{array}$ & media cetak dan online dan jurnal \\
\hline
\end{tabular}

Melihat luaran dan indikator pencapaiannya serta hasil evaluasi, kegiatan ini telah mencapai target yang diharapkan. Namun demikian, diperlukan kegiatan-kegiatan berkelanjutan secara terus menerus untuk memotivasi difabel agar terus berkarya dan berdaya melalui pemasaran digital. Dibutuhkan pula peran dan dukungan dari pemerintah dan berbagai pihak untuk mendorong agar difabel dapat mendiri secara ekonomi.

Publikasi pada jurnal ilmiah merupakan bentuk penyebarluasan ilmu pengetahuan juga sebagai ruang diskusi mengenai metode pengabdian dan luaran diantara akademisi. Kemudian publikasi pada media massa menjadi salah satu cara untuk menghapuskan stigma negatif yang menempel pada kelompok difabel sekaligus sebuah komitmen serta upaya menarik kerjasama dan dukungan dari seluruh elemen masyarakat. Dari kegiatan ini, perubahan yang terjadi tidak hanya di level individu maupun kelompok difabel, melainkan juga di masyarakat secara umum. Dengan perkembangan teknologi yang begitu pesat dan digitalisasi di berbagai bidang, pengembangan kemandirian melalui digital marketing bagi difabel ini ke depannya masih sangat relevan untuk terus dilakukan.

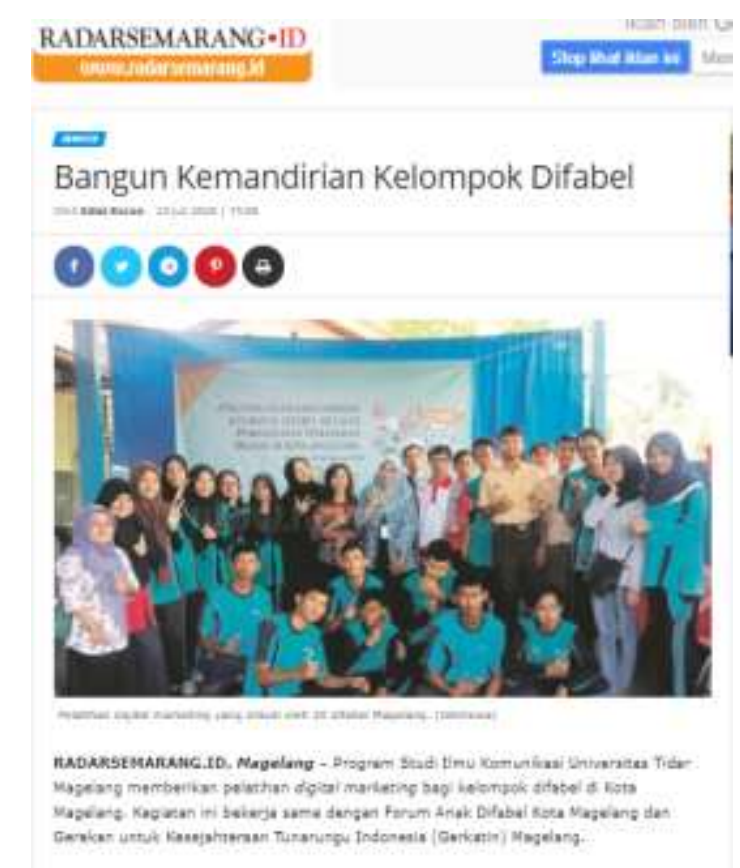

Gambar 4. Publikasi Kegiatan di Media Massa 


\section{KESIMPULAN}

- Kegiatan pengabdian kepada ini menghasilkan peningkatkan pemahaman dan keterampilan masyarakat, khususnya kelompok difabel sebagai mitranya.

- Selama ini mitra memang sudah banyak menghasilkan produk dan terampil dalam mengolah limbah untuk dijadikan berbagai produk. Kini mitra juga menjadi terampil dalam memasarkan produknya di media sosial sehingga produknya dikenal oleh masyarakat.

- Kelebihan dari kegiatan pengabdian yang sudah berlangsung adalah antusias peserta dalam kegiatan dan mudah dalam mempelajari materi karena perangkat yang digunakan adalah gawai yang sehari-hari mereka gunakan untuk komunikasi. Aplikasi-aplikasi yang digunakan pun mudah digunakan dan dapat didownload gratis. Metode learning by doing juga efektif digunakan pada kegiatan pengabdian dengna mitra difabel.

- Beberapa kelemahan yang dihadapi adalah tidak semua pemateri bisa menggunaakan bahasa isyarat dengan baik sehingga seringkali terjadi miskomunikasi dengan peserta. Demikian juga dengan peserta yang memiliki keterbatasan dalam komunikasi verbal, baik tulisan maupun lisan sehingga fasilitator dan guru penting dalam proses belajar.

- Terbentuknya komunitas penggiat digital marketing (Digipreneur Magelang) merupakan upaya menjamin keberlangsungan kegiatan ini.

- Komunitas perlu diaktifkan dengan berbagai kegiatan yang menambah keterampilan di bidang digital marketing.

\section{UCAPAN TERIMA KASIH}

Pada kesempatan ini Penulis mengucapkan terima kasih kepada Universitas Tidar yang telah memberikan dukungan dalam pendanaan sehingga kegiatan ini dapat berjalan dengan lancar. Terima kasih kami sampaikan kepada SLB-B YPPALB Kota Magelang yang telah menyediakan tempat, perlengkapan, serta membantu dalam penyediaan fasilitator dari guru-guru SLB. Selanjutnya penulis juga mengucapkan terima kasih kepada mitra pengabdian, dalam hal ini Forum Anak Difabel Kota Magelang maupun Gerkatin Magelang yang telah bekerjasama hingga terlaksananya kegiatan ini.

\section{DAFTAR PUSTAKA}

Azizah, Nisaul., Erly Rofianti Wahyudi, Khoirrun Nissa, Amelia Fibrianti Wahyudi, Siti Khoiruli Ummah. (2019). Pemberdayaan Istri Nelayan Melalui Pelatihan Digital Marketing Strategy (Dms) Darah Biru. Jurnal Dinamisia, 3(1), 131-141.

Antonius Satria Hadi, Antonius Satria dan Ardhi Khairi. (2020). Pemilihan Strategi Pemasaran di Era Digital pada Kelompok Ibu PKK Desa Gadingharjo. Jurnal Dinamisia, 4(1), 127-132.

Dewojati, R. Kuncoro Wulan. (2009). Desain Grafis Sebagai Media Ungkap Periklanan. Imaji:Jurnal Seni dan Pendidikan Seni, 7(2), 175-182

Kusuma, Diana Fitri dan Mohamad Syahriar Sugandi. (2018). Strategi Pemanfaatan Instagram Sebagai Media Komunikasi Pemasaran Digital Yang Dilakukan Oleh Dino Donuts. Jurnal Manajemen Komunikasi, 3(1), 18-33.

Oktaviani, Femi dan Rustandi, Diki. (2018). Implementasi Digital Marketing dalam Membangun Brand Awareness. PRofesi Humas, 3(1), 1-20

Ramdan, Angelita Kania., Fuad Riski Rismawan, Nadiah Wiharnis dan Dini Safitri. (2019). Pengaruh Akun Instagram @temandisabilitas_Id dalam Meningkatkan Kesadaran Followers Terhadap Difabel. Inter Komunikasi: Jurnal Komunikasi, 4(2), 104-115. 
Sholehah, Iffatus. (2017). Pemberdayaan Difabel Melalui Asset Based Approach Studi Kasus di Dusun Piring Desa Srihardono Kabupaten Bantul Oleh Rehabilitasi Terpadu Penyandang Disabilitas. Jurnal Pemberdayaan Masyarakat: Media Pemikiran dan Dakwah Pembangunan, 1(1), 157-176.

Purwanto, Yudhy S. dan Mira Veranita. (2018). Pelatihan Fotografi Dasar Bagi Pelaku Usaha Kecil Dan Menengah (UKM) Kecamatan Lengkong Kota Bandung. Jurnal Dharma Bakti Ekuitas, 2(2), 2015-211.

Puspitarini, Dinda Sekar dan Nuraeni, Reni. (2018). Pemanfaatan Media Sosial Sebagai Media Promosi. Jurnal Common, 3(1), 71-80

Vinaika, Raj dan Dhruva Manik. (2017). How Instagram is Changing the Way Marketing Works?. International Journal of Management and Business Studies, 7(4), 12-16.

Alagöz, Selda Basaran dan Nezahat Ekici. (2016). The New Phenomenon Of The Marketing World In The Digital Era: Content Marketing. International Journal of Economics, Commerce and Management, 4(12), 639-646.

Pemda Kota Magelang. (2016). Rencana Pembangunan Jangka Menengah Daerah (RPJMD) Kota Magelang Tahun 2016-2021. Magelang: Pemkot Magelang.

Kingsnorth, Simon. (2016). Digital Marketing Strategy: An Integrated Approach To Online Marketing. United Kingdom: Kogan Page.

Rahman, Arief. (2016). Pendekatan Partisipatif Dalam Pengembangan Komunitas. Modul Antara Pengembangan Komunitas, Partisipasi, dan Pemberdayaan. Program Perencanaan dan Pengembangan Komunitas P4W-LPPM IPB.

Hoai Do, Phuong. (2018). The Impact Of Product Photography On Consumer Attention And Perception. Thesis. Arcada University of Applied Sciences diunduh dari https://pdfs.semanticscholar.org/53d7/a300a30c2743edc61732db1b642ca40d56fc.pdf pada 20 Juli 2020 pukukl 13.01 WIB.

Sucahyo, Nurhadi. (2019). Teknologi Buka Peluang Kerja Baru untuk Difabel. 20 September, 2019, diunduh dari https://www.voaindonesia.com/a/teknologi-buka-peluang-kerja-baruuntuk-difabel/5091776.html.

Undang - Undang (UU) RI No.4 Tahun 1997 Tentang Penyandang Cacat. 